\title{
The Impact of Electronic Word of Mouth on Consumers' Purchasing Decisions
}

\author{
Amal M. Almana \\ PhD Student \\ College of Computer and Information Sciences \\ King Saud University, Riyadh, Saudi Arabia
}

\author{
Abdulrahman A. Mirza \\ Professor \\ College of Computer and Information Sciences \\ King Saud University, Riyadh, Saudi Arabia
}

\begin{abstract}
The substantial growth in online social networks has vastly expanded the potential impact of electronic word of mouth (eWOM) on consumer purchasing decisions. A critical literature review exposed that there is limited research on the impact of online consumer reviews on online purchasing decisions of Saudi Arabian consumers. This research reports on results of a study on the effects of online reviews on Saudi citizens' online purchasing decisions. The results show that Saudi Internet shoppers are very much influenced by eWOM, and that a larger percentage of them are dependent on such online forums when making decisions to purchase products through the Internet.
\end{abstract}

\section{General Terms}

E-commerce, online shopping reviews.

\section{Keywords}

Electronic word of mouth; eWOM; online WOM; online consumer reviews; Saudi Arabia

\section{INTRODUCTION}

The traditional Word of Mouth (WOM) is a mode of communication that was described originally as a means of sharing opinion and comments as regards to the products and services that people were transacting [1]. However, word of mouth has evolved into an entirely new form of communication that exploits modern technology. This is termed as electronic word of mouth (eWOM) communication. The advent and growth of the digital age built on the foundation of computing and the Internet has seen the development and adoption of new ways of accessing and assessing consumer trends. Consumers have embraced and will continually tap the importance of Web 2.0 tools in the exchange of opinions, posting of comments, reviews, and critiques on the digital platform. The digital platform is constituted of weblogs, newsgroups, discussion forums, social network websites, review websites, and online newspaper columns. Truly, word of mouth has found a new way to assert its value to product marketing in new forms of communication [2].

One type of eWOM is online consumer reviews, it consists of analyses and commentaries generated and posted by the end users of products who have spent their money on the product and indeed used it. It is a credible source of consumer insight and it can be used by businesses to make corrective or improvement measures on their products and services. Through online reviews, different customers share their shopping experiences. Online shoppers always undertake a review of other shoppers' comments and experiences before they buy products online. Online reviews provide an essential component of online shopping decisions as the amount of perceived risk involved is extremely high. Many potential online shoppers frequently wait for comments of other shoppers before taking up an offer. Such information is obtained from online customer review platforms [3]. Electronic WOM communications form a concrete and exciting area of research. Over the past few years, there has been substantial growth in eWOM communities, however, there is a noticeable lack of research on the phenomenon in Saudi Arabia. There are limited publications as regards to the subject and with reference to the effect that online reviews have on online consumers' decisions in Saudi Arabia.

This paper studies the effect of online reviews on purchasing decisions in Saudi Arabia. It looks at the impact that online reviews have on consumer purchasing decisions taking into consideration the reviewers' reputation and the website's reputation as a reliable source of information. From a scholarly point of view, the research is geared at providing a deep insight on ways of improving our understanding of the impact of online reviews on online shoppers purchasing decisions in the context of Saudi Arabia as one major developing country in the Middle East.

\section{LITERATURE REVIEW}

EWOM refers to any attempt by a former, potential, or actual customer to highlight the positive or negative attributes of a product or company in an online platform [4]. Although eWOM presents a high similarity in terms of characteristics with traditional WOM communication, it presents an entirely new perspective to WOM. One notable and unique characteristic that eWOM has is the fact that it reaches or can reach more than one member of a group. EWOM introduces a capability of WOM reaching an unprecedented number of people all at once. Millions of people have access to a single online review, and this is where the power of eWOM lies [4] [2].

The advent of the Internet has amplified the effects that eWOM has on consumers. Khammash (2008) quantitatively looked into one form of eWOM, online consumer reviews, and the reasons as to why consumers rely on product reviews prior to making conclusions on whether or not to order or purchase a product online. He elucidated that the drivers for seeking other's opinions in online consumer reviews bear differentiated levels of effect on different aspects of consumer behavior. A conclusion was made that online consumer reviews have been used as a bases for consumers' search for information and that they do have an effect on their purchasing behavior. Online consumer reviews serve as decision aids, consumer feedback mechanisms, and a recommendation system in an online shopping platform [5]. 
The writing style of the online review, the reviewer's expertise, and timeliness of the online review are the factors that determine the helpfulness of an online review. Yang, et. al. (2008) came up with a nonlinear model to predict the usefulness of reviews, and gave a detailed rendition of crucial factors that affect the usefulness of a review [6]. Hu \& Wu (2009) developed a score index algorithm backed with a sentence-weight classification scheme to classify all the sentences in consumer reviews into either the pros list or cons list and then summarized both lists. This summarization list is useful for online consumers to make decision before purchasing [7].

Cheng \& Thadani (2010) determined stimulus, communicator, response, and receiver as the key components of their conceptual framework designed to investigate the effects of eWOM at an individual level. Factors related to those four elements are identified and classified [2]. It has also been found by Bae \& Lee (2011) that online reviews are adopted by consumers in the light of reducing perceived risk of negative effects of online shopping. This can influence their attitude towards a certain product and ultimately their purchasing decision [8].

Do-Hyung et al. researched the effect of different types of review and the quantity of such reviews on consumer intention to purchase online. The research showed that experienced shoppers regard the type of review highly for making purchasing decisions unlike novices. In addition, the number of reviews affects novices as compared to experienced shoppers [9]. The research by Do-Hyung et al. supports that of Cheung et al. through a lab experiment that shows that online reviews have an effect on online consumer behavior. They reinforce the finding that negative online consumer reviews are detrimental to consumers' emotional trust and affect their decision to purchase a product or service [3]. Kamtrain established that online consumers' behavioral intention is shaped significantly by perceived value, trust, and eWOM [10].Chen showed in his research that there is a positive relation between online comments and recommendations and shopping experience, shopping satisfaction, and shopping intention [11].

Fan and Miao developed an expanded Elaboration Likelihood model with a wider perspective that exhibited that gender has an effect on the credibility of eWOM communication content, its acceptance, and ultimately the consumer purchasing decision intention. They also showed that perceived eWOM credibility had a significant effect on eWOM acceptance and intent to purchase [12]. Bae et al. in their research highlighted that different genders react differently to online reviews. According to them, online reviews have stronger effects on males than on females. In addition, negative reviews had stronger effects on females than positive reviews, which also affected their purchasing decisions. They also found that females perceive online shopping as riskier than men do. As such, they are more hesitant to adopt it than men are. However, online reviews have the effect of mitigating the risk profile and encouraging them to buy [8].

At the regional level, two online communities: Saudi Arabia and Kuwait were investigated for their use of eWOM for consumer behavior analysis. Al-Haidari and Coughlan propped up a continuance usage framework analyzing the use of eWOM. This framework was developed based on three crucial models: the information acquisition model, the information system continuance model, and the WOM process model [13]. Alballaa and Mirza investigated the usage of eWOM by Saudi female consumers. The study showed that the majority of participants find eWOM to be important, and that $83 \%$ of them do read eWOM. The authors further identifies that a positive shopping experience will lead to participation in the writing of eWOM more than a negative experience [14].

\section{PPROPOSED RESEARCH}

The aim of this research is to determine how the Saudi online consumers view and react to the eWOM. We will be looking to answer some of the following questions:

- Do online reviews affect the general Saudi consumer's purchasing behavior?

- Do characteristics of online reviews such as consistency, frequency, recency, and, correctness of written text impact the consumer's purchasing decision?

- Do product review ratings influence the decisions to purchase?

- Do characteristics of the reviewers such as identity, gender, age, residence, or, frequency of participation affect the consumer's purchasing decision?

- Do characteristics of the web site offering online reviews such as reliability, popularity, and, international reach affect the consumer's purchase decision?

\section{METHODOLOGY}

\subsection{Participants}

For the present study, different members of the Saudi population including both male and female citizens were invited to answer the questionnaire. Invitees included university faculty and students studying in Saudi Arabia or abroad. The general public and professionals were also contacted through Twitter and WhatsApp and asked to participate. However, we requested that only those with an online purchasing experience participate in taking the study. We were able to collect 150 valid responses to the study.

\subsection{Instrument}

The research technique applied in this study is a questionnaire using a 5-point Likert scale, from 1 (indicating fully disagree) to 5 (indicating fully agree). A total of 27 questions were contained in the questionnaire including demographic information (questions 1 to 7 ) and three other factors, characteristics of online reviews (questions 8 to 17), characteristics of reviewer (questions 18-23), and the website that presented the online review (questions 24-27).

\subsection{Procedure}

The questionnaire was posted on Google Docs. When conducting the questionnaire people were asked to provide their basic demographic information first; then answer questions in each factor accordingly. Because the study was set up such that all questions must be answered before being able to proceed to the following section and to make the final submission at the end of the questionnaire, all the questionnaires collected by this research were complete.

\section{RESULTS AND DATA ANALYSIS}

The average reliability coefficient for this research was used to ensure that measures of factors are reliable. After analyzing the data, the average reliability coefficient (Cronbach's Alpha) for all parts of the survey was found to be 0.832 , which exceeded the recommended level of 0.70 . This indicates that the reliability of factors was acceptable for internal 
consistency. A three-week period was allocated for collecting participants' answers to help us in identifying the effects of online reviews on consumers' purchasing decisions of Saudi Arabian citizens. All study participants were classified as frequent online shoppers.

\subsection{Demographic Analysis}

The majority of participants were females at $64 \%$ while male represented only $36 \%$ of the sample size. Out of the sample, $81.3 \%$ were between the ages of 20 and $35.16 \%$ were above 35 years of age, and $2.7 \%$ were under 20 . A significant number of respondents, 64\%, were living in Saudi Arabia, compared with $17.3 \%$ living in Canada, $16.7 \%$ living in the UK, and, $2 \%$ living in the United States.

The respondents were categorized into four educational levels. Among the respondents, those with undergraduate and master's degree were the majority of respondents representing collectively $70.7 \%$ of the overall number of participants. $40.7 \%$ had bachelor's degrees while $30 \%$ had a master's degree. The remaining respondents, representing $29.3 \%$ of the total participants, were divided into $14 \%$ below undergraduate degrees, while $15.3 \%$ were with $\mathrm{PhD}$ degrees. The percentage of respondents with an average monthly income of less than or equal to Saudi Riyals (SR) 10,000 was $45.4 \%$. Those with salaries above SR 10,000 and up to SR 20,000 accounted for $42 \%$ of the total respondents, while those with salaries above SR 20,000 represented only $12.7 \%$ of the sample size.

About $32.7 \%$ of the study participants had an average Internet usage of 21 hours or more per week, $46 \%$ used the Internet 10 hours or less per week, while $21.3 \%$ used it between $11-20$ hours per week. As expected, and in accordance with the findings of Alballaa and Mirza (2013), the majority of respondents represented by $80.7 \%$ of the total participants used to read the online reviews before making a purchasing decision. In summary, the descriptive statistics of the demographic information of our study sample is shown in Table 1 and Figures 1-6.

Table 1. Demographic analysis of the sample

\begin{tabular}{|c|c|c|c|c|c|c|c|}
\hline \multicolumn{2}{|c|}{ Characteristics } & \multirow{2}{*}{$\begin{array}{c}\text { Frequency } \\
4\end{array}$} & \multirow{2}{*}{$\begin{array}{c}\text { Percent } \\
2.7\end{array}$} & \multicolumn{2}{|c|}{ Characteristics } & \multirow{2}{*}{$\begin{array}{c}\text { Frequency } \\
34\end{array}$} & \multirow{2}{*}{$\begin{array}{r}\text { Percent } \\
22.7\end{array}$} \\
\hline & Under 20 & & & \multirow{6}{*}{$\begin{array}{c}\text { Average income } \\
\text { per month (Saudi } \\
\text { Riyals) }\end{array}$} & Below 5000 & & \\
\hline & $20-25$ & 41 & 27.3 & & $5001-10000$ & 34 & 22.7 \\
\hline \multirow{4}{*}{ Age } & $26-30$ & 52 & 34.7 & & $10001-15000$ & 42 & 28.0 \\
\hline & $31-35$ & 29 & 19.3 & & $15001-20000$ & 21 & 14.0 \\
\hline & $36-40$ & 15 & 10.0 & & $20001-25000$ & 7 & 4.7 \\
\hline & Above 40 & 9 & 6.0 & & 25001 or more & 12 & 8.0 \\
\hline \multirow{2}{*}{ Gender } & Male & 54 & 36.0 & \multirow{2}{*}{$\begin{array}{l}\text { Do you read } \\
\text { reviews before } \\
\text { purchase? }\end{array}$} & Yes & 121 & 80.7 \\
\hline & Female & 96 & 64.0 & & No & 29 & 19.3 \\
\hline \multirow{4}{*}{$\begin{array}{l}\text { Currently you } \\
\text { are living in }\end{array}$} & USA & 3 & 2.0 & \multirow{4}{*}{ Education level } & $\begin{array}{c}\text { Lower than } \\
\text { Bachelor degree }\end{array}$ & 21 & 14.0 \\
\hline & Canada & 26 & 17.3 & & Bachelor degree & 61 & 40.7 \\
\hline & UK & 25 & 16.7 & & Master degree & 45 & 30.0 \\
\hline & KSA & 96 & 64.0 & & $\mathrm{PhD}$ & 23 & 15.3 \\
\hline \multirow{2}{*}{$\begin{array}{c}\text { Frequency of } \\
\text { internet usage } \\
\text { in a week }\end{array}$} & $1-5$ Hours & 27 & 18.0 & \multirow{2}{*}{$\begin{array}{c}\text { Frequency of } \\
\text { internet usage in a } \\
\text { week }\end{array}$} & $11-20$ Hours & 32 & 21.3 \\
\hline & $6-10$ Hours & 42 & 28.0 & & 21 Hours or more & 49 & 32.7 \\
\hline
\end{tabular}




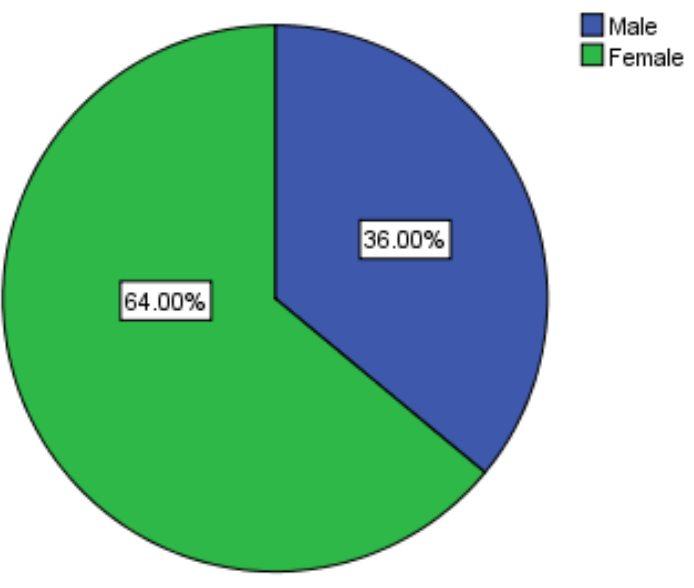

Fig 1: Participants gender distribution

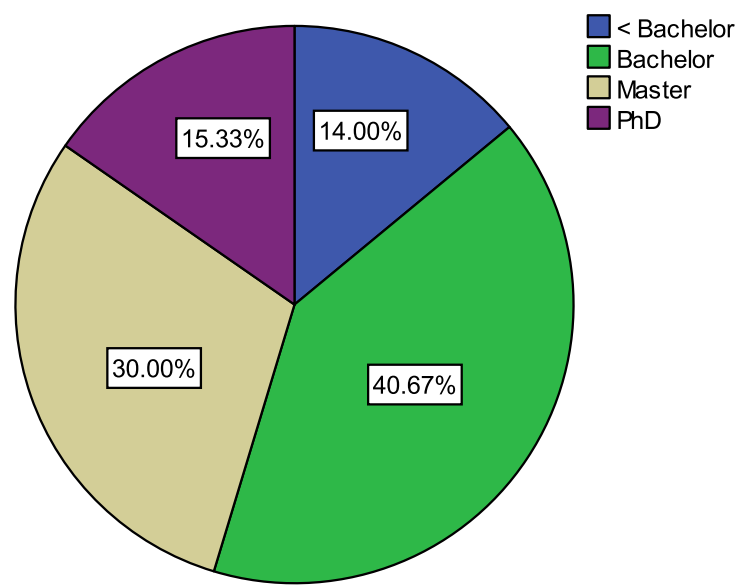

Fig 3: Participants educational level distribution

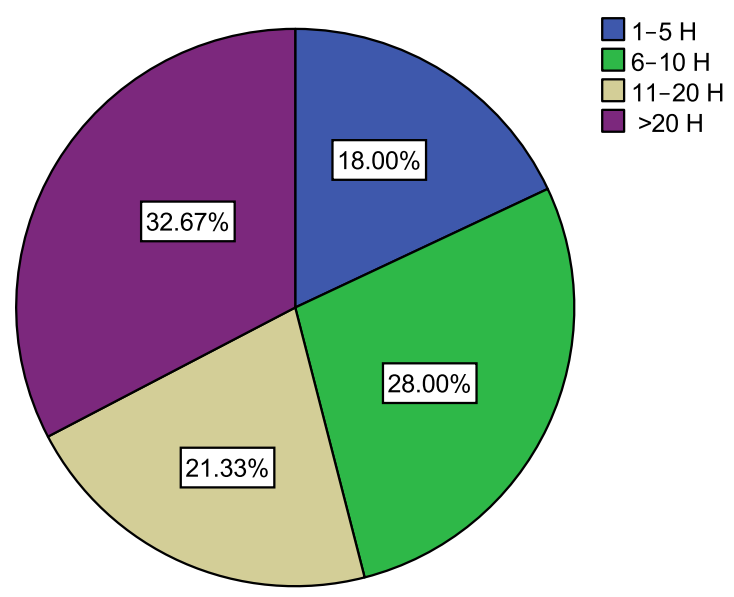

Fig 5: Participants internet usage

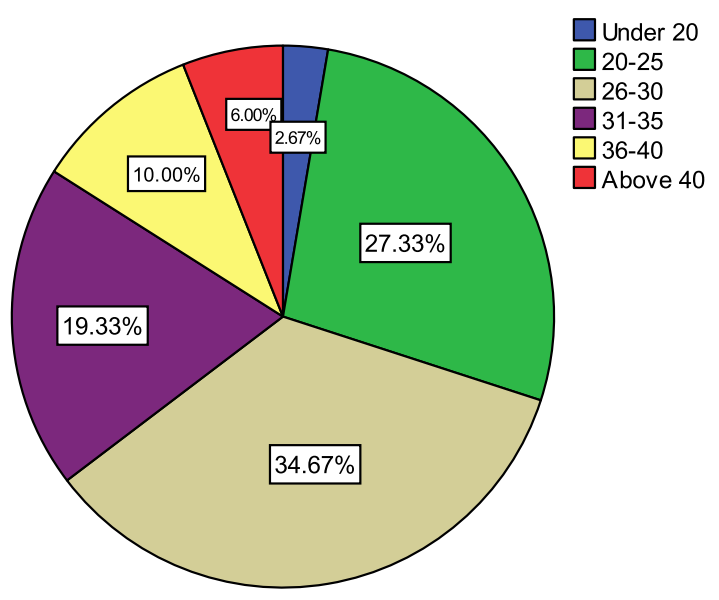

Fig 2: Participants age distribution

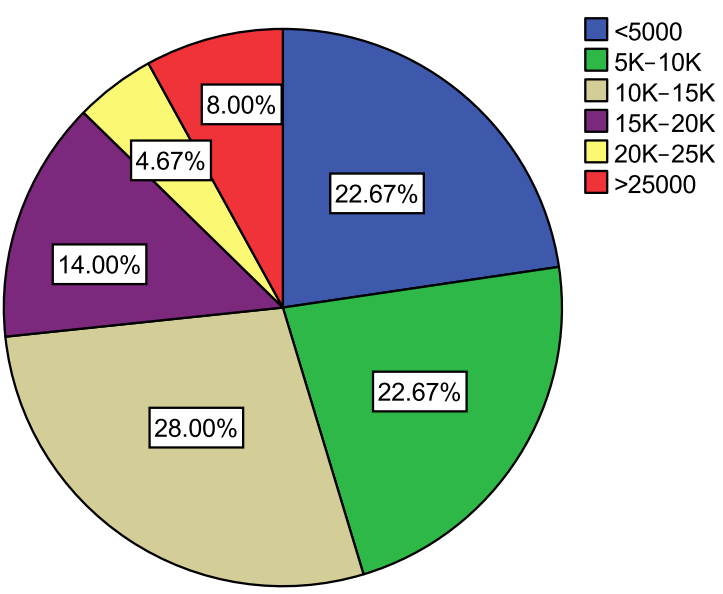

Fig 4: Participants monthly income distribution

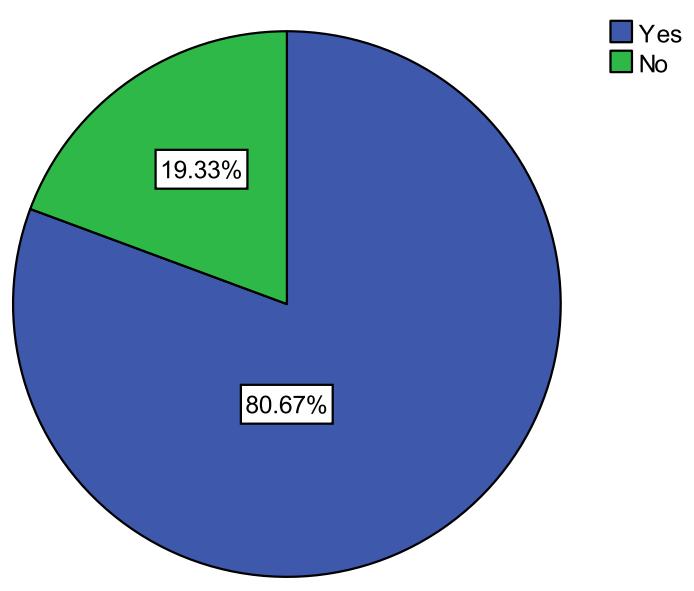

Fig 6: Do you read online review before purchasing? 


\subsection{Online Consumer Reviews Analysis}

After answering all the demographic questions, the second part of the survey investigates the different factors and characteristics of reviews that might have an impact on consumers. This part is divided into three main subsections, the first is related to the characteristics of the reviews themselves. It consists of ten statements that seek to determine the reaction of the shoppers to the consumer reviews. The second subsection highlights the characteristics of the reviewer, it includes six statements that explore the nature of the writer of the review and the influence of such character on purchasing decisions (Table 3). The third subsection contains four questions that consider the characteristics of the websites that bear the consumer reviews and the influence of those website characteristics on the decision making process of making a purchase or otherwise (Table 4).

Tables 2, 3, and 4 highlight the descriptive statistics obtained from the participant's responses of the survey. The first column of each of the three tables represents the statements of the questionnaire. The subsequent columns represent the 5point Likert scale predefined responses available to the respondents. Also it contains the frequency (number of responses) and the corresponding percentage of the study population that chose a certain alternative among the five predetermined responses. The subsequent columns express the mean, standard deviation and the rank. The mean and standard deviation are derived from the number of responses across all five predefined responses. The rank is derived from the mean where the lower rank refers to the statement with the highest level of agreement by the study participants.

\subsubsection{Analysis Related to Characteristics of the \\ Review}

According to Table 2, $60 \%$ of the total participants agreed and fully agreed with the statement that the consistency of the reviews that were posted on the website had an impact on their purchasing decisions. This is in contrast with the portion of respondents of only $11.3 \%$ who disagreed and fully disagreed that consistency is an important factor when making a purchasing decision. $28.7 \%$ of respondents were neutral on this issue. With regard to the importance of a website's product reviews on the decision making of consumers, $68 \%$ of participants agree and strongly agree that such reviews are helpful when deciding to make a purchase. On the other hand, $12.6 \%$ of the participants were in disagreement and full disagreement with the value of product reviews on their decision to make a purchase. $19.3 \%$ were indifferent about the value of such reviews.

On the issue of whether product reviews are biased or not, $40.7 \%$ of the total participants were neutral or undecided on this topic. $30.7 \%$ agreed that customer reviews are not biased, while $10 \%$ strongly believed the same. $14.7 \%$ thought that reviews were biased, while an additional $4 \%$ believed the same strongly. When it came to the issue of how recent a review was posted, $34 \%$ of respondents indicated that this is an important deciding factor when making a purchase. An additional $20.7 \%$ feels the same with a stronger conviction. $30.7 \%$ of participants are neutral on this matter, while a combined $14.7 \%$ don't feel such an importance with disagree and strong disagree selections. On the effect of negative or positive reviews when purchasing more expensive goods, $50.7 \%$ were in agreement that negative reviews were important influencers when making purchasing decisions of expensive goods, while $44.7 \%$ are in agreement with the influence of positive comments on purchasing decisions. $17.4 \%$ did not agree that negative comments would have an effect on the purchase of expensive goods, while $20 \%$ did not agree that positive comments would affect their purchasing decisions of expensive goods. $32 \%$ and $35.2 \%$ are respectively neutral about the effect of such reviews.

The top ranked statement in this section of the questionnaire with a mean of 3.86 is the one related to the impact of highly rated products through online reviews. A total of $65.4 \%$ agreed and strongly agreed with the value of such a rating on their decision making process. $25.3 \%$ had a neutral stance on this issue, while a combined $9.4 \%$ disagreed and totally disagreed with such a statement. 59.3\% of study participants agree that the number of product reviews affected their purchase decision. $14.7 \%$ of the respondents disagreed with this statement, while $24 \%$ took a neutral position. $54 \%$ of participants agree that they feel concerned had they not read the reviews on a purchased product. $21.3 \%$ do not regret not reading reviews, while $24.7 \%$ are neutral on the matter. Spelling or grammar mistakes in product reviews have the least impact on purchasing decisions and is therefore ranked as the least factor effecting decisions to make a purchase with a mean of 2.65 . Only $23.3 \%$ agree that such mistakes have an impact on their purchasing decisions while $48 \%$ are not impacted by such problems.

Table 2. Statements of respondents about consumer reviews

\begin{tabular}{|c|c|c|c|c|c|c|c|c|c|}
\hline \multicolumn{2}{|l|}{ Statement } & \multirow{2}{*}{$\begin{array}{c}\begin{array}{c}\text { Fully } \\
\text { Disagree }\end{array} \\
\text { (1) } \\
9\end{array}$} & \multirow{2}{*}{$\begin{array}{c}\text { Disagree } \\
\text { (2) } \\
8\end{array}$} & \multirow{2}{*}{$\begin{array}{c}\text { Neutral } \\
\text { (3) } \\
43\end{array}$} & \multirow{2}{*}{$\begin{array}{c}\text { Agree } \\
\begin{array}{c}\text { (4) } \\
43\end{array}\end{array}$} & \multirow{2}{*}{$\begin{array}{c}\begin{array}{c}\text { Fully } \\
\text { Agree }\end{array} \\
\text { (5) } \\
47\end{array}$} & \multirow{3}{*}{$\begin{array}{c}\text { Mean } \\
3.74\end{array}$} & \multirow{3}{*}{$\begin{array}{c}\text { SD } \\
\\
1.138\end{array}$} & \multirow{3}{*}{$\begin{array}{c}\text { Rank } \\
3\end{array}$} \\
\hline \multirow{2}{*}{$\begin{array}{l}\text { Consistency of reviews posted on the } \\
\text { website affect my purchase }\end{array}$} & $\mathrm{F}$ & & & & & & & & \\
\hline & $\%$ & 6 & 5.3 & 28.7 & 28.7 & 31.3 & & & \\
\hline \multirow{2}{*}{$\begin{array}{l}\text { When I buy a product online, the } \\
\text { reviews presented on the website are } \\
\text { helpful for my decision making }\end{array}$} & $\mathrm{F}$ & 8 & 11 & 29 & 57 & 45 & \multirow{2}{*}{3.80} & \multirow{2}{*}{1.111} & \multirow{2}{*}{2} \\
\hline & $\%$ & 5.3 & 7.3 & 19.3 & 38 & 30 & & & \\
\hline
\end{tabular}




\begin{tabular}{|c|c|c|c|c|c|c|c|c|c|}
\hline \multirow{2}{*}{$\begin{array}{l}\text { I believe that the product reviews on } \\
\text { the internet are neutral (not bias) }\end{array}$} & $\mathrm{F}$ & 6 & 22 & 61 & 46 & 15 & \multirow{2}{*}{3.28} & \multirow{2}{*}{.970} & \multirow{2}{*}{9} \\
\hline & $\%$ & 4 & 14.7 & 40.7 & 30.7 & 10 & & & \\
\hline \multirow{2}{*}{$\begin{array}{l}\text { Recency of product reviews posted on } \\
\text { the website affect my purchase } \\
\text { decision }\end{array}$} & $\bar{F}$ & 7 & 15 & 46 & 51 & 31 & \multirow{2}{*}{3.56} & \multirow[b]{2}{*}{1.071} & \multirow{2}{*}{5} \\
\hline & $\%$ & 4.7 & 10 & 30.7 & 34 & 20.7 & & & \\
\hline \multirow{2}{*}{$\begin{array}{l}\text { When I buy a product online, the } \\
\text { impact of negative online reviews on } \\
\text { my purchasing decision is greater for } \\
\text { expensive goods }\end{array}$} & $\bar{F}$ & 13 & 13 & 48 & 33 & 43 & \multirow[b]{2}{*}{3.53} & \multirow[b]{2}{*}{1.235} & \multirow[b]{2}{*}{6} \\
\hline & $\%$ & 8.7 & 8.7 & 32 & 22 & 28.7 & & & \\
\hline \multirow{2}{*}{$\begin{array}{l}\text { When I buy a product online, the } \\
\text { impact of positive online reviews on } \\
\text { my purchasing decision is greater for } \\
\text { expensive goods }\end{array}$} & $\mathrm{F}$ & 9 & 21 & 53 & 43 & 24 & \multirow{2}{*}{3.35} & \multirow{2}{*}{1.093} & \multirow{2}{*}{8} \\
\hline & $\%$ & 6 & 14 & 35.3 & 28.7 & 16 & & & \\
\hline \multirow{2}{*}{$\begin{array}{l}\text { Received high ratings for product } \\
\text { affect my purchase decision }\end{array}$} & $F$ & 4 & 10 & 38 & 49 & 49 & \multirow{2}{*}{3.86} & \multirow{2}{*}{1.036} & \multirow{2}{*}{1} \\
\hline & $\%$ & 2.7 & 6.7 & 25.3 & 32.7 & 32.7 & & & \\
\hline \multirow{2}{*}{$\begin{array}{l}\text { The number of product reviews affects } \\
\text { my purchase decision }\end{array}$} & $\mathrm{F}$ & 7 & 15 & 39 & 54 & 35 & \multirow{2}{*}{3.63} & \multirow{2}{*}{1.089} & \multirow{2}{*}{4} \\
\hline & $\%$ & 4.7 & 10 & 26 & 36 & 23.3 & & & \\
\hline \multirow{2}{*}{$\begin{array}{l}\text { If I don't read the reviews presented } \\
\text { on the website when I buy a product } \\
\text { online. I worry about my decision }\end{array}$} & $\mathrm{F}$ & 14 & 18 & 37 & 44 & 37 & \multirow{2}{*}{3.48} & \multirow{2}{*}{1.246} & \multirow{2}{*}{7} \\
\hline & $\%$ & 9.3 & 12 & 24.7 & 29.3 & 24.7 & & & \\
\hline \multirow{2}{*}{$\begin{array}{l}\text { Spelling or grammar mistakes in } \\
\text { product review affect my purchase } \\
\text { decision }\end{array}$} & $\mathrm{F}$ & 33 & 39 & 43 & 17 & 18 & \multirow{2}{*}{2.65} & \multirow{2}{*}{1.274} & \multirow{2}{*}{10} \\
\hline & $\%$ & 22 & 26 & 28 & 11.3 & 12 & & & \\
\hline
\end{tabular}

\subsubsection{Analysis Related to Characteristics of the}

\section{Reviewer}

Table 3 details the respondents' attitudes towards the actual product reviewers. According to the results presented the "Other reviewers' rating of usefulness of the review affects my purchase decision" is regarded as more important than other statements in this section with a mean of 3.38 and a standard deviation of $1.047 .43 .3 \%$ of the total number of participants agreed and fully agreed on the effect of rating of usefulness of the review by other reviewers on the consumer purchasing decision while a combined $16 \%$ disagreed and totally disagreed with such a statement. $40.7 \%$ had a neutral stance on this issue. Therefore, it's suggested that other reviewers' evaluations of reviews should be presented to customers.

Forty Eight percent $(48 \%)$ of the total participants disagree and fully disagreed with the fact that the nick name or the real name of the reviewers affected their purchase decision. 25.3\% believe that naming is critical, while $26.7 \%$ are neutral on the matter. On the issue of whether the frequency of reviews submitted by a specific reviewer affects the purchasing decisions or not, $38 \%$ of the total participants were neutral or undecided on this issue. $32.7 \%$ of the total participants agreed and fully agreed that the frequency of reviews written by certain reviewer affected their purchasing decision, while 29.4 $\%$ of the participants were in disagreement and complete disagreement with the statement. $36.7 \%$ were in disagreement and full disagreement of the opinion that the reviewer age affects the purchase decision. However, $34.7 \%$ believe otherwise, while $28.7 \%$ were neutral. When we asked about the reviewer residence and its affect on the purchase decision, the responses were more or less similar and followed a similar pattern. $38.7 \%$ of the respondents disagreed and fully disagreed with the effect of a reviewer's residency. $26.6 \%$ fully agreed with the statement regarding the reviewer residency while $34.7 \%$ were neutral.

The reviewer gender have the least impact on purchasing decisions and it therefore came-in sixth and last place among other statements in this section with a mean of 2.48 and a standard deviation of 1.186 . Only $21.3 \%$ agree and strongly agree that the reviewer's gender makes a big difference on their purchasing decision while $49.3 \%$ do not believe the same. $29.3 \%$ of respondents were neutral on this issue. The factor of reviewer gender, nick or real names, and residence are assessed with the least influence on purchasing decisions. In general it can be said that Saudi online shoppers do not consider demographic profiles of reviewers as significant factors when making purchasing decisions. 
Table 3. Statements of respondents about the reviewer

\begin{tabular}{|c|c|c|c|c|c|c|c|c|c|}
\hline \multicolumn{2}{|l|}{ Statement } & \multirow{2}{*}{$\begin{array}{c}\begin{array}{c}\text { Fully } \\
\text { Disagree }\end{array} \\
(1) \\
8\end{array}$} & \multirow{2}{*}{$\begin{array}{c}\text { Disagree } \\
\begin{array}{c}(2) \\
16\end{array}\end{array}$} & \multirow{2}{*}{$\begin{array}{c}\text { Neutral } \\
\text { (3) } \\
61\end{array}$} & \multirow{2}{*}{$\begin{array}{l}\text { Agree } \\
\text { (4) } \\
41\end{array}$} & \multirow{2}{*}{$\begin{array}{c}\begin{array}{c}\text { Fully } \\
\text { Agree }\end{array} \\
(5) \\
24\end{array}$} & \multirow{3}{*}{$\begin{array}{c}\text { Mean } \\
3.38\end{array}$} & \multirow{3}{*}{$\begin{array}{c}\text { SD } \\
1.047\end{array}$} & \multirow{3}{*}{$\begin{array}{c}\text { Rank } \\
1\end{array}$} \\
\hline \multirow{2}{*}{$\begin{array}{l}\text { Other reviewers' rating of usefulness of the } \\
\text { review affects my purchase decision }\end{array}$} & $\mathrm{F}$ & & & & & & & & \\
\hline & $\%$ & 5.3 & 10.7 & 40.7 & 27.3 & 16 & & & \\
\hline \multirow{2}{*}{$\begin{array}{l}\text { The nick name or the real name of the } \\
\text { reviewers affects my buying decision }\end{array}$} & $\mathrm{F}$ & 42 & 30 & 40 & 26 & 12 & \multirow{2}{*}{2.57} & \multirow{2}{*}{1.281} & \multirow{2}{*}{5} \\
\hline & $\%$ & 28 & 20 & 26.7 & 17.3 & 8 & & & \\
\hline \multirow{2}{*}{$\begin{array}{l}\text { The frequency of reviews submitted by a } \\
\text { specific reviewer affects my purchasing } \\
\text { decisions }\end{array}$} & $\mathrm{F}$ & 19 & 25 & 57 & 39 & 10 & \multirow{2}{*}{2.97} & \multirow{2}{*}{1.099} & \multirow{2}{*}{2} \\
\hline & $\%$ & 12.7 & 16.7 & 38 & 26 & 6.7 & & & \\
\hline \multirow{2}{*}{$\begin{array}{l}\text { The reviewer's age affect my purchase } \\
\text { decision }\end{array}$} & $\mathrm{F}$ & 25 & 30 & 43 & 42 & 10 & \multirow[b]{2}{*}{2.88} & \multirow[b]{2}{*}{1.187} & \multirow[b]{2}{*}{3} \\
\hline & $\%$ & 16.7 & 20 & 28.7 & 28 & 6.7 & & & \\
\hline \multirow{2}{*}{$\begin{array}{l}\text { The reviewer's residence affects my } \\
\text { purchase decision }\end{array}$} & $\mathrm{F}$ & 25 & 33 & 52 & 32 & 8 & \multirow[b]{2}{*}{2.77} & \multirow[b]{2}{*}{1.126} & \multirow[b]{2}{*}{4} \\
\hline & $\%$ & 16.7 & 22 & 34.7 & 21.3 & 5.3 & & & \\
\hline \multirow{2}{*}{$\begin{array}{l}\text { The reviewer's gender affects my purchase } \\
\text { decision }\end{array}$} & $\mathrm{F}$ & 42 & 32 & 44 & 26 & 6 & \multirow{2}{*}{2.48} & \multirow{2}{*}{1.186} & \multirow{2}{*}{6} \\
\hline & $\%$ & 28 & 21.3 & 29.3 & 17.3 & 4 & & & \\
\hline
\end{tabular}

\subsubsection{Analysis Related to Characteristics of the Websites that Present the Reviews}

Statements and nature of respondents' replies with regard to websites that present product or service reviews are provided in Table 4. As the table shows, $64 \%$ of participants agree and strongly agree that the reliability of a website is important when deciding to make a purchase. On the other hand, only $20.3 \%$ of the participants were in disagreement and full disagreement with the statement. $22 \%$ were neutral on the matter. Concerning the issue of the internationality of the web site that presents the reviews and its effect on the purchase decision, $33.3 \%$ of respondents indicated that this is an important deciding factor when making a purchase. An additional $22.7 \%$ feels the same with a stronger assurance. $32.7 \%$ of participants are neutral on this topic, while a combined $11.3 \%$ don't feel such an importance with disagree and strong disagree choices.

With regard to the popularity of a website that present the review on the decision making of consumers, this factor came in first place among other statements where the average of 3.87 and a standard deviation of 1.053 . This indicates that the participants agree to the importance of the popularity of the web site. $67.4 \%$ of the total number of participants agreed and fully agreed on the effect of the web site popularity on the consumer purchasing decision whereas $10 \%$ of the total participants disagreed and fully disagreed with the statement. $22.7 \%$ were indifferent about the value of popular website.

The statement, "If the web site that present the reviews belong to the company whose product I want to buy, my purchasing decision is effected," scored the lowest mean 3.52 across all four statements under the website section and it therefore ranked as the least effective factor, with a standard deviation of 1.001 . $51.4 \%$ of the total number of participants agreed and fully agreed on this phrase whereas $11.4 \%$ of them were of a contrary opinion. $37.3 \%$ of respondents were neutral on this issue. Very much like the review itself, the website that present the review is a critical factor in the decision making process of the consumer. It is apparent that the ownership of the website by the company whose product I want to buy, the more desirable and trustful the review will be. Consequently, more than half of the sample $51.4 \%$ establishes a greater trust when those reviews belong to the company's website. Therefore, it can be recommended that popularity, reliability, internationality, and ownership of the website are critical for Saudi consumer respectively. 
Table 4. Statements of respondents about websites that present product or services reviews

\begin{tabular}{|c|c|c|c|c|c|c|c|c|c|}
\hline \multicolumn{2}{|l|}{ Statement } & $\begin{array}{c}\text { Fully } \\
\text { Disagree } \\
\text { (1) }\end{array}$ & $\begin{array}{c}\text { Disagree } \\
\text { (2) }\end{array}$ & $\begin{array}{c}\text { Neutral } \\
\text { (3) }\end{array}$ & $\begin{array}{l}\text { Agree } \\
\text { (4) }\end{array}$ & $\begin{array}{c}\text { Fully } \\
\text { Agree } \\
\text { (5) }\end{array}$ & Mean & SD & Rank \\
\hline \multirow{2}{*}{$\begin{array}{l}\text { Reliability of the site that present the reviews } \\
\text { affect my purchase decision }\end{array}$} & $\mathrm{F}$ & 1 & 20 & 33 & 48 & 48 & \multirow{2}{*}{3.81} & \multirow{2}{*}{1.052} & \multirow{2}{*}{2} \\
\hline & $\%$ & 0.7 & 13.3 & 22 & 32 & 32 & & & \\
\hline \multirow{2}{*}{$\begin{array}{l}\text { Internationality of the web site that present the } \\
\text { reviews affect my purchase decision }\end{array}$} & $F$ & 8 & 9 & 49 & 50 & 34 & \multirow{2}{*}{3.62} & \multirow{2}{*}{1.066} & \multirow{2}{*}{3} \\
\hline & $\%$ & 5.3 & 6 & 32.7 & 33.3 & 22.7 & & & \\
\hline \multirow{2}{*}{$\begin{array}{l}\text { Popularity of web site that present the reviews } \\
\text { affect my purchase decision }\end{array}$} & $\mathrm{F}$ & 5 & 10 & 34 & 52 & 49 & \multirow{2}{*}{3.87} & \multirow{2}{*}{1.053} & \multirow{2}{*}{1} \\
\hline & $\%$ & 3.3 & 6.7 & 22.7 & 34.7 & 32.7 & & & \\
\hline \multirow{2}{*}{$\begin{array}{l}\text { If the web site that present the reviews belong } \\
\text { to the company whose product I want to buy, } \\
\text { my purchasing decision is effected }\end{array}$} & $\mathrm{F}$ & 7 & 10 & 56 & 52 & 25 & \multirow{2}{*}{3.52} & \multirow{2}{*}{1.001} & \multirow{2}{*}{4} \\
\hline & $\%$ & 4.7 & 6.7 & 37.3 & 34.7 & 16.7 & & & \\
\hline
\end{tabular}

\section{CONCLUSION}

Many consumers surf the web to read online comments and reviews about products or services they are interested in. This research has shown that such comments and reviews are important factors that help Saudi consumers in making purchasing decisions. More than $80 \%$ of the study participants have indicated that they read online reviews before making an online purchase. The study has also shown that higher ratings and characteristics of reviews are effective factors for making purchasing decisions. In particular, consistency, number of online reviews, and, recency of reviews are important factors on a purchasing decisions.

Of least significance on the online Saudi consumer's purchase decision process is the demographic profile of reviewers. Finally, the study has shown that there is a great agreement on the importance of the popularity of the website on which reviews are being read. Popularity, reliability, internationality, and ownership of the website all help in the making of Saudi consumers' purchasing decisions.

\section{REFERENCES}

[1] S. Aslam, E. Jadoon, K. Zaman and S. Gondal, "Effect of Word of Mouth on Consumer Buying Behavior," Mediterranean Journal of Social Sciences, 2011.

[2] C. M. Cheung and D. R. Thadani, "The Effectiveness of Electronic Word-of-Mouth Communication: A Literature Analysis," in BLED 2010 Proceedings., 2010.

[3] C. M. Cheung and M. K. Lee, "Online Consumer Reviews: Does Negative Electronic Word-of-Mouth Hurt More?," in 14th Americas Conference on Information Systems (AMCIS), Toronto, 2008.

[4] T. Hennig-Thurau, K. P. Gwinner, G. Walsh and D. D. Gremler, "Electronic wordof mouth via consumeropinion platforms: What motivates consumers to articulate themselves on the Internet?," Journal of Interactive Marketing, pp. 38-52, 2004.

[5] M. Khammash, "Electronic word-of-mouth: Antecedents of reading customer reviews in on-line opinion platforms: A quantitative study from the UK market," in IADIS International Conference, 2008.

[6] L. Yang, H. Xiangji and A. Aijun, "Modeling and Predicting the Helpfulness of Online Reviews," in Eighth IEEE International Conference on Data Mining, 2008.

[7] X. Hu and B. Wu, "Classification and Summarization of Pros and Cons for Customer Reviews," in IEEE/WIC/ACM International Joint Conferences on Web Intelligence and Intelligent Agent , 2009.

[8] S. Bae and T. Lee, "Gender differences in consumers perception of online consumer reviews," Electronic Commerce Research, pp. 201-214, 2011.

[9] P. Do-Hyung and S. Kim, "The effects of consumer knowledge on message processing of electronic word-ofmouth via online consumer reviews," Electronic Commerce Research and Applications, pp. 399-410, 2008.

[10] M. Kamtarin, "The Effect of Electronic Word of Mouth, Trust and Perceived Value on Behavioral Intention from the Perspective of Consumers," Academic Research in Economics and Management Sciences, 2012.

[11] H. Chen, "The Impact of Comments and Recommendation System on Online Shopper Buying Behaviour," Journal of Networks, 2012.

[12] Y.-W. Fan and Y.-F. Mia, "Effect Of Electronic WordOf-Mouth On Consumer Purchase Intention:The Perspective Of Gender Differences," International Journal of Electronic Business Management, pp. 175$181,2012$. 
[13] N. Al-Haidari and J. Coughlan, "Investigating continuance usage of e-WOM in online communities," in International Conference on Information Society (iSociety 2012), 2012.

[14] H. Alballaa and A. Mirza, "Factors Influencing Online Word-of-Mouth In Virtual Communities In Saudi Arabia," in Southwest Decision Sciences Institute 44th Annual Meeting, Albaqurque, NM, USA, March 12-16, 2013.

[15] P. Chatterjee, "Online Reviews - Do Consumers Use Them?," in ACR 2001 Proceedings, 2001.
[16] B. Brown, "Beyond Recommendations: Local Review Web Sites and Their Impact," ACM Trans. Comput.Hum. Interact., 2012.

[17] T. Hennig-Thurau, K. P. Gwinner, G. Walsh and D. D. Gremler, "Electronic wordof mouth via consumeropinion platforms: What motivates consumers to articulate themselves on the Internet?,"Journal of Interactive Marketing, pp. 38-52, 2004

[18] C. M. Cheung and D. R. Thadani, "The State of Electronic Word of Mouth Research: A Literature Analysis," in PACIS 2010 Proceedings, 2010. 